\title{
Blended Learning Berbasis Modul Elektronik Bidang Studi IPA Di Mts. Surabaya Limbangan Garut
}

\author{
Nuraeni ${ }^{\# 1}$

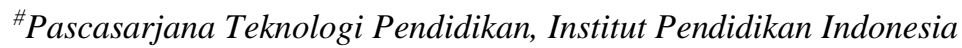 \\ Jalan Pahlawan No. 32 Sukagali Tarogong Garut \\ nuraeninur607@gmail.com
}

\begin{abstract}
Almost all countries in the world and our country Indonesia are no exception, having an impact on the Coronavirus Disease (Covid-19) Pandemic, which requires the government to issue policies in various sectors to immediately take a stand in preventing wider transmission, including the education sector. The new period to normal due to the Covid19 pandemic is indeed an extraordinary struggle in the field of education. In the midst of various prevention and cure efforts due to a virus where the anti-vaccine has yet to be found, all sectors are compiling new life protocols, which means we carry out various facts in all aspects of life. Here my role as a parent, teacher, government, and community member must have many strategies in adjusting the learning conditions in schools during this pandemic. Currently, the Distance Learning process still utilizes the Whatsapp group facility in smart phone devices. The teacher provides lesson materials and assignments to students through the Whatsapp group, both through the parents' group and their respective class groups. One of the efforts to overcome these problems in the learning process in this new normal period, will be more effective with a blended learning approach and approach. The blended learning approach, which combines online and offline approaches. The blended learning approach, of course with all its advantages and disadvantages, tends to be used as a strategic alternative. The purpose of this study is to determine teacher teaching activities, student learning activities, and student responses in the application of Blended Learning.
\end{abstract}

Keywords_Mixed Learning, Electronic Module, Science (Science)

Abstrak - Hampir di seluruh Negara di dunia dan tidak terkecuali Negara kita Indonesia, merasakan dampak Pandemi Coronavirus Disease (Covid-19), yang mengharuskan pemerintah mengeluarkan kebijakan di berbagai sektor untuk segera mengambil sikap dalam mencegah penularan yang lebih luas, termasuk sektor pendidikan. Masa new normal akibat pandemic covid19 memang luar biasa perjuangannya dalam bidang pendidikan. Di tengah berbagai upaya pencegahan dan penyembuhan akibat virus yang belum ditemukan antivaksinnya ini membuat semua sector menyusun berbagai protokoler kehidupan baru yang artinya kita melakukam berbagai penyesuaian di semua lini kehidupan. Disini peran saya sebagai orang tua, guru, pegawai pemerintahan, dan bagian masyarakat harus punya banyak strategi dalam menyesuaikan kondisi pembelajaran disekolah di masa pandemic ini. Proses Pembelajaran Jarak Jauh saat ini masih memanfaatkan fasilitas grup Whatsapp dalam perangkat smart phone. Guru memberikan materi pelajaran dan tugas kepada para peserta didik melalui grup Whatsapp, baik melalui grup orang tua siswa maupun grup kelas masing-masing. Salah satu upaya untuk mengatasi kendala tersebut dalam Proses pembelajaran di masa new normal ini, akan lebih efektif dengan mengunakan pendekatan dan mekanisme blended learning. Pendekatan blended learning, yakni menggabungkan pendekatan daring dan luring. pendekatan blended learning, tentu dengan segala kelebihan dan kekurangannya, cenderung dapat dijadikan alternatif strategis.. Tujuan Pengkajian ini adalah untuk mengetahui kegiatan mengajar guru, kegiatan belajar siswa, dan respon siswa dalam penerapan pembelajaran Blended Learning.

Kata Kunci - Pembelajaran Campuran, Modul Elektronik, IPA (Science)

\section{PENDAHULUAN}

Hampir di seluruh Negara di dunia dan tidak terkecuali Negara kita Indonesia, merasakan dampak Pandemi Coronavirus Disease (Covid-19), yang mengharuskan mengeluarkan kebijakan di berbagai sektor untuk segera mengambil sikap dalam mencegah penularan yang lebih luas, termasuk sektor pendidikan. Di beberapa daerah proses pembelajaran dari rumah telah berlangsung sejak 16 Maret 2020 dan diperpanjang sampai tahun pelajaran baru 20202021 yang mulai efektif masuk hari Senin tanggal 13 Juli
2020, dengan mempertimbangkan situasi di masing-masing daerah. Mengantisipasi penularan virus tersebut pemerintah telah mengeluarkan berbagai kebijakan, seperti isolasi, social and physical distancing hingga pembatasan sosial berskala besar (PSBB). Kondisi ini mengharuskan warganya untuk tetap stay at home, bekerja, beribadah dan belajar di rumah.[1]Dunia pendidikan memiliki taruhan jangka panjang, yang akan berpengaruh terhadap kelangsungan sumberdaya manusia dan masa depan Indonesia sendiri. Jika tanpa pencermatan dan kesungguhan rencana yang tepat atas 
dampak covid-19, maka berkemungkinan besar generasi terdidik bangsa ini menjadi korban dan klaster penularan covid-19 yang sangat massif. Dalam posisi ini, loss generation secara fisik terhadap sumber daya manusia mendatang menjadi kenyataan pahit bagi bangsa ini. Oleh karenanya, kita patut untuk melihat akan dinamika pelaksanaan kebijakan new normal dan dampaknya terhadap kelangsungan pendidikan.

Tidak adanya kepastian di saat pandemi Covid-19 melanda Indonesia, membuat dunia pendidikan khususnya sekolah juga harus melakukan reorientasi dalam banyak hal, khususnya penyelenggaraan kurikulum di satuan pendidikan. Meskipun dibuat skema protokoler agar bidang pendidikan tetap berlangsung nanti di masa new normal, namun rencana penyelenggaraan proses pembelajaran secara langsung berbasis Luring menuai banyak kritikan dan juga penuh kekhawatiran.

Proses pembelajaran jarak jauh saat ini masih memanfaatkan fasilitas grup Whatsapp dalam perangkat smart phone dan google classrom. Guru maupun memberikan materi pelajaran dan tugas kepada para peserta didik melalui grup Whatsapp, baik melalui grup orang tua siswa maupun grup kelas masing-masing. Waktu belajar sesuai dengan jadwal mata pelajaran harian. Materi belajar dipelajari secara mandiri kemudian dilanjutkan dengan mengerjakan tugas harian. Diskusi terkait materi yang dipelajari dilakukan melalui grup tersebut. Untuk mengadakan tatap muka virtual dapat menggunakan video call dengan penggunaan WAG sebagai alternative lain penggunaan aplikasi Google Classroom, sebagai media lainnya. Dengan fitur ini, guru bisa memantau kehadiran dan keaktifan peserta didik.[2][3]

Berdasarkan latar belakang dan identifikasi masalah seperti yang telah dipaparkan sebelumnya, agar analisis masalah dapat rinci dan tajam dengan memperhatikan keterbatasan biaya dan waktu yang dimiliki, maka dalam penelitian ini ruang lingkup permasalahan dibatasi hanya pada kondisi peserta didik dalam pembelajaran Campuran (Blended Learning) Dengan Penggunaan E-Modul IPA, maka pengkajian ini mengambil judul "Pembelajaran Campuran (Blended Learning) Dengan Penggunaan EModul IPA Di Mts.Surabaya Limbangan Garut Di Masa New Normal". Tujuan pengkajian ini adalah sebagai berikut, (1) Untuk mengetahui kegiatan mengajar guru dalam Pembelajaran Campuran (Blended Learning) Dengan Penggunaan E-Modul IPA Di Mts.Surabaya Limbangan Garut Di Masa New Normal. (2) Untuk mengetahui kegiatan belajar siswa dalam Pembelajaran Campuran (Blended Learning) Dengan Penggunaan E-Modul IPA Di Mts.Surabaya Limbangan Garut Di Masa New Normal. (3) Untuk mengetahui respon siswa pada Pembelajaran Campuran (Blended Learning) Dengan Penggunaan EModul IPA Di Mts.Surabaya Limbangan Garut Di Masa New Normal.

TINJAUAN PUSTAKa

A. Pembelajaran
Pembelajaran adalah perpaduan dari dua aktivitas, yaitu aktivitas mengajar dan aktivitas belajar. Aktivitas mengajar menyangkut peranan seorang guru dalam konteks mengupayakan terciptanya jalinan komunikasi harmonis antara pengajar itu sendiri dengan si belajar. (Rivai, Metode Mengajar dalam www. google.com).

( Pengertian Pembelajaran Menurut Para Ahli )

Ciri-ciri dari pembelajaran dalam bukunya Sugandi, dkk (2000:25) antara lain:

1. Pembelajaran dilakukan secara sadar dan direncanakan secara sistematis;

2. Pembelajaran dapat menumbuhkan perhatian dan motivasi siswa dalam belajar;

3. Pembelajaran dapat menyediakan bahan belajar yang menarik dan menantang bagi siswa;

4. Pembelajaran dapat menggunakan alat bantu belajar yang tepat dan menarik;

5. Pembelajaran dapat menciptakan suasana belajar yang aman dan menyenangkan bagi siswa;

6. Pembelajaran dapat membuat siswa siap menerima pelajaran baik secara fisik maupun psikologis.

Tujuan pembelajaran adalah perubahan prilaku dan tingkah laku yang positif dari peserta didik setelah mengikuti kegiatan belajar mengajar, seperti: perubahan yang secara psikologis akan tampil dalam tingkah laku (over behaviour) yang dapat diamati melalui alat indera oleh orang lain baik tutur katanya, motorik dan gaya hidupnya.

Hal ini dapat disimpulkan bahwa proses pembelajaran merupakan proses melibatkan guru dengan semua komponen tujuan, bahan, metode dan alat serta penilaian. Jadi proses pembelajaran merupakan suatu sistem yang saling terkait antar komponennya di dalam mencapai suatu tujuan yang telah ditetapkan.

\section{B. Pembelajaran Campuran (Blended Learning)}

Pembelajaran merupakan upaya peningkatan kemampuan yang multi-dimensi. Melalui berbagai input dan sumber belajar yang berbeda, upaya peningkatan itu dilakukan. Dalam konteks ini, dapat dipahami bila terjadi pergeseran tren utama pembelajaran, dari guru-terpusat kepada muridterpusat [4] Berbagai model pendekatan pembelajaran itu tampaknya akan melangkah menuju titik yang dapat menggabungkan elemen-elemen terbaik dari berbagai pendekatan pembelajaran. Titik inilah yang disebut dengan hybrid learning, mixed learning atau blended learning.

Pada titik ini, tampaknya pembelajaran campuran tidak hanya metode yang berciri khas menggabungkan dua hal, yaitu pembelajaran dan pelatihan, namun ia juga menjadi tren pembelajaran yang fashionable. dari Indiana University mengidentifikasi setidaknya ada 10 tren blended learning dewasa ini, yaitu (1) Mobile blended learning; (2) Greater visualization, Individualization, \& Hands-on Learning; (3) Self-Determined Blended Learning; (4) Increased Conntectedness, Community \& Collaboration, (5) Increased Authenticity \& on-Demand Learning; (6) Linking Work \& Learning; (7) Changed Calendaring; (8) Blended Learning 
Course Designations; (9) Changed Instructor Roles; dan (10) The Emergence of Blended Learning Specialists. [5]

Menurut Deni Darmawan. 2014 hal 39 dalam upaya mewujudkan konsep pembelajaran modern, diharapkan mampu menggabungkan produk dari kelompok software intelllegence dan hardware intelllegence yang memunculkan konsep belajar quatum learning, accelerated learning, integrated learning dan sejenis lainnya. Pembelajaran berbasis teknologi informasi yaitu animation learning, games learning, tutorial computer based learning, baik secara audio, visual, audiovisual dan multimedia dengan virtual learning. Realitas yang di harapkan ini justru mampu diwujudkan melalui konsep e-learning.

Penerapan blended learning secara substantif mencoba menggabungkan "pendekatan campuran" yang terdiri atas pembelajaran berbasis online, pembelajaran tatap-muka (face to face) dan pembelajaran berbasis naskah (paper-based learning) [6] (.Terkait "hubungan tripartit" ini, berbagai pendekatan pembelajaran berfungsi sebagai pendukung pendekatan pembelajaran tatap muka. [7]

Blended learning pada dasarnya merupakan gabungan keunggulan pembelajaran yang dilakukan secara tatap muka (face to face learning) dan secara virtual (e-learning). Pembelajaran online atau e-learning dalam blended learning menjadi perpanjangan alami dari pembelajaran ruang kelas tradisional yang menggunakan model tatap muka (face to face learning).

Berdasarkan penjelasan di atas maka dapat disimpulkan bahwa blended learning adalah pembelajaran yang merupakan gabungan antara pembelajaran dengan elektronik berbasis web (e-learning) dengan pembelajaran secara tatap muka di kelas. Blended learning merupakan pembelajaran yang memanfaatkan teknologi informasi berupa e-learning sebagai media dalam menyampaikan pembelajaran dan untuk meningkatkan motivasi belajar siswa dengan pembelajaran yang lebih modern dan menarik. Proses pembelajaran dengan blended learning akan lebih efektif karena proses pembelajaran yang biasanya dilakukan secara conventional atau tatap muka akan dibantu dengan pembelajaran secara web atau e-learning dengan teknologi informasi yang bisa dilakukan kapanpun dan dimanapun.

Pembelajaran dengan blended learning dapat menggeser prinsip pembelajaran dari teacher center menuju student center secara dinamis. Pembelajaran blended learning bersifat saling melengkapi kekurang pembelajaran face to face learning dan e-learning, sebab menurut Munir, kelemahan pembelajaran e-learning adalah siswa dan guru terpisah secara fisik sehingga interaksi secara tatap muka menjadi berkurang. E-elearning cenderung pada pelatihan daripada pendidikan yang mengarah pada kemampuan kognitif dan psikomotirk dan kurang memperhatikan aspek afektif. Pembelajaran dengan face to face learning guru mampu memfungsikan dirinya sebagai pendidik dan memberikan dorongan motivasi secara langsung dan ekspresif kepada siswa. Blended learning membuat aktifitas siswa dalam kelas menjadi lebih variatif.
Tujuan blended learning adalah untuk menggabungkan pengalaman belajar kelas tatap muka dengan pengalaman belajar secara online,. Secara keseluruhan, model blended learning mengacu kepada integrasi atau campuran yang disebut e-learning, alat dan teknik pengiriman tugas dengan pengajaran tatap muka tradisional yang digambarkan sebagai berikut:

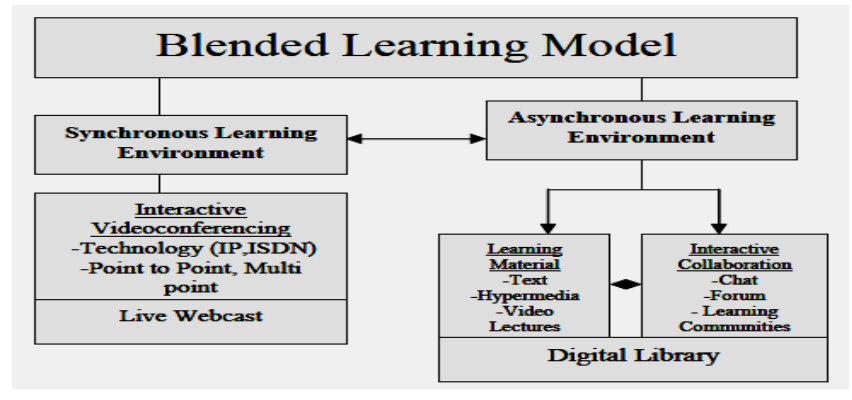

Gambar 1. Model Blended Learning (Negash. S, Wilcox. MV, 2008)

C. Ilmu pengetahuan alam atau sains (science)

Ilmu pengetahuan alam atau sains (science) diambil dari kata latin Scientia yang arti harfiahnya adalah pengetahuan, tetapi kemudian berkembang menjadi khusus Ilmu Pengetahuan Alam atau Sains. Sund dan Trowbribge merumuskan bahwa Sains merupakan kumpulan pengetahuan dan proses.

Sedangkan Kuslan Stone menyebutkan bahwa Sains adalah kumpulan pengetahuan dan cara-cara untuk mendapatkan dan mempergunakan pengetahuan itu. Sains merupakan produk dan proses yang tidak dapat dipisahkan. Sains sebagai proses merupakan langkah-langkah yang ditempuh para ilmuwan untuk melakukan penyelidikan dalam rangka mencari penjelasan tentang gejala-gejala alam Langkah tersebut adalah merumuskan masalah, merumuskan hipotesis, merancang eksperimen, mengumpulkan data, menganalisis dan akhimya menyimpulkan. Dari sini tampak bahwa karakteristik yang mendasar dari Sains ialah kuantifikasi artinya gejala alam dapat berbentuk kuantitas. [8]

\section{E-Modul}

E-modul merupakan kata dasar dari kata e - dan modul. Pengertian modul menurut Departemant Pendidikan Nasional, Modul ialah bahan belajar yang dirancang secara sistematis berdasarkan kurikulum tertentu dan dikemas dalam bentuk satuan pembelajaran terkecil dan memungkinkan dipelajari secara mandiri dalam satuan waktu tertentu. Modul adalah alat atau saranapembelajaran yang berisi materi, metode, batasan-batasan meteri pembelajaran, petunjuk kegiatan belajar, latihan, dan cara mengevaluasi yang dirancan secara sistematis dan bahasa yang komunikatif dan menarik untuk mencapai kompetensi yang diharapkan dan dapat digunakan secara mandiri. [9]

Kata dasar berukutnya dari e-modul adalah e- berarti electronik yang pada kaitan ini mengacu pada e-learning. learning adalah penggunaan informasi dan teknologi komputer untuk membuat pengalaman belajar. [9]. Bicara 
mengenai komponen yang ada pada e-modul bisa di adopsi dari komponen pada modul media cetak. Komponenkomponen utama yang perlu tersedia di dalam modul,yaitu tinjauan mata pelajaran, pendahuluan, kegiatan belajar, latihan, rambu-rambu jawaban latihan, rangkuman, tes formatif, dan kunci jawaban tes formatif.

Modul elektronik yang dikembangkan menggunakan software 3D Pageflip Professional memiliki tampilan yang sangat menarik, karena dengan menggunakan software 3D Pageflip modul memiliki tampilan seperti sebuah buku yang sesungguhnya. Dimana modul elektronik berbasis 3D Pageflip Professional bisa bergerak seperti membolakbalikkan sebuah buku, bisa menampilkan gambar, audio, animasi dan video yang membuat pengguna (guru atau siswa) merasa tertarik untuk menggunakannya dalam proses pembelajaran. Oleh sebab itu, sebelum menggunakan 3D Pageflip Professional guru harus mendesain tampilan modul elektronik dengan sangat menarik agar dalam proses pembelajaran siswa merasa senang, tidak mudah bosan atau jenuh dan materi pembelajaran yang disampaikan oleh guru dapat mereka serap dengan mudah, serta tujuan dari pembelajaran dapat tercapai.[10]

\section{METODE PENELITIAN}

Metode Penggunaan e-modul sebagai bahan ajar yang memanfaatan teknologi bisa mempermudah guru untuk memberikan materi IPA kepada siswa, Metode Penelitian yang digunakan dalam penelitian ini adalah metode survai dengan teknik korelasional dengan. Untuk itu penelitian ini bertujuan untuk mengembangkan produk pembelajaran yang akan digunakan disekolah.

Penelitian yang memfokuskan pada pengembangan produk, baik produk industri maupun produk pembelajaran dalam dunia sekolah yang diuji secara sistematis di lapangan, dievaluasi, dan disempurnakan hingga memenuhi kriteria efektif, dan bermutu sehingga layak untuk digunakan. Model ADDIE terdiri dari 5 tahap, yaitu tahap Analisis, Desain, Pengembangan, Implementasi, dan Evaluasi. [11]

Tahap analisis merupakan tahapan pertama sebelum mengembangkan produk. Pada tahap ini kebutuhan dan tujuan dari pembelajaran dianalisis terhadap apa yang akan dipelajari oleh siswa. Tahap desain terdiri dari penyusunan isi modul elektronik seperti materi, cerita, prakarya dan penyusunan instrumen. Pada tahap pengembangan dikembangkan bahan ajar berupa modul elektronik etnokontruktivisme berbasis 3D Pageflip Professional. Setelah tahap pengembangan dilakukan implementasi yang diuji cobakan kepada siswa kelas 5 sekolah dasar untuk mengetahui persepsi, minat dan motivasi siswa. Tahap terakhit yaitu tahap evaluasi, tahap ini dilakukan dengan melakukan uji kelayakan modul elektronik etnokontruktivisme berbasis 3D Pageflip Professional. [11]

Dalam penelitian ini, terdapat validitas konten yang dilakukan melalui konsultasi dengan para ahli (Kriteria validasi Penilaian Pakar) sesuai dengan bidangnya. Uji validitas dalam penelitian ini melibatkan ahli media.
Validitas konten dapat dilihat dari kesesuaian produk dengan tuntutan kurikulum

Aplikasi pembelajaran dibangun menggunakan metode Prototype. Metode ini membagi tahapan pembangunan konten pembelajaran kedalam tiga bagian: "Listen to Customer", "Build/Revise Mock-Up", dan "Customer Test Drives Mock-Up. Model Prototype dilakukan secara berulang hingga aplikasi yang dihasilkan sesuai dengan kebutuhan dan kesepakatan penggunanya. [12]

\section{A. Listen to Customer}

Tahap Listen to Customer adalah tahap pertama dari model prototype . Pada tahap ini dilakukan komunikasi dan mendengarkan kebutuhan terkait pembuatan konten aplikasi pembelajaran dari guru untuk merumuskan dan menentukan format, media dan materi pembelajaran yang akan dibangun.

\section{B. Build/Revise Mock- up}

Tahap kedua dilakukan pembangunan mock-up aplikasi pembelajaranya itu membangun media pembelajaran. Proses pembangunan mock-up dilakukan secara berulang - ulang dan periodic hingga sesuai dengan keinginan pengguna yaitu guru.

\section{Customer Test Drives Mock- up}

Hasil akhir dari aplikasi pembelajaran kemudian dievaluasi oleh beberapa pihak yaitu : guru, siswa yang akan dan sudah pernah mengambil mata pelajaran tersebut.

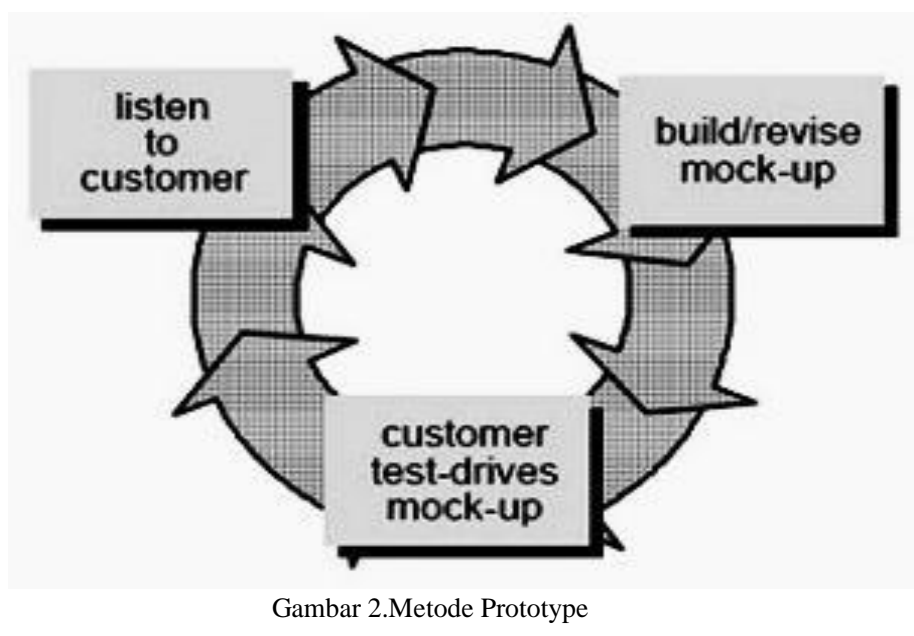

Pengkajian ini merupakan pengkajian tindakan kelas (classroom action research). Pengkajian Tindakan pembelajaran tatap muka dalah pengkajian dengan memberikan serangkaian perlakuan (treatment) secara terencana yang digunakan untuk meningkatkan kemampuan subjek yang diteliti (Sukardi, 2012: 211). Desain Pengkajian Tindakan Kelas mengacu pada Model Kemmis, yang dikembangkan oleh Stephen Kemmis dan Robin Mc Taggart, yang terdiri atas empat komponen, yaitu perencanaan, pelaksanaan tindakan, observasi dan refleksi (Sukardi, 2012: 214-215).

Karena Work From Home (WFH) selama 4 bulan mulai dari pertengahan bulan Maret sampai Pertengahan bulan Juni 2020 maka untuk lokasi dilaksanakan di rumah dengan survai 
terus keaktifan kegitan proses pembelajaran lewat Whatsapp dan classroom dalam perangkat smart phone dan laptop. Waktu pengkajian dilaksanakan selama dua bulan mulai bulan April dan Mei pada semester genap tahun pelajaran 2019/2020.

Populasi adalah keseluruhan subjek pengkajian . Populasi dalam pengkajian ini adalah seluruh siswa kelas IX MTs. Surabaya Limbangan Garut yang terdiri dari kelas kelas IX A dengan Jumlah 31 peserta didik dan kelas IX B berjumlah . Sampel adalah sebagian atau wakil populasi yang diteliti. Sampel dalam pengkajian ini adalah siswa kelas 1X B dengan jumlahi 32 peserta didik.

Pengkajian dilaksanakan dalam 2 siklus, setiap siklus terdiri dari 2 pertemuan. Tahapan pengkajian berupa perencanaan (penyusunan perangkat pembelajaran dan instrumen pengkajian), tindakan (melaksanakan kegiatan pembelajaran dengan strategi blended learning), pengamatan/observasi (mengamati kegiatan guru dan siswa selama pembelajaran), dan refleksi (mengkasi hasil pelaksanaan pembelajaran blended learning).

Perangkat pembelajaran yang digunakan berupa media pembelajaran (e-learning), silabus, rencana pelaksanaan pembelajaran (RPP), lembar penilaian (LP), dan materi ajar/hand out. observasi kegiatan mengajar guru dan kegiatan belajar siswa, pengecekan respon siswa pada proses pembelajaran lewat Whatsapp dan classroom dalam perangkat smart phone dan laptop.

\section{HASIL DAN PEMBAHASAN}

Pembuatan model pembelajaran ini dengan menggunakan metode blended learning yaitu menggabungkan pembelajaran online dan konvensional.

A. Pembelajaran secara Online melalui Web-based

Web-based course adalah penggunaan internet untuk keperluan pembelajaran, dimana seluruh bagian bahan belajar, diskusi, konsultasi, chatting, penugasan, latihan quiz dapat diakses secara online melalui internet.

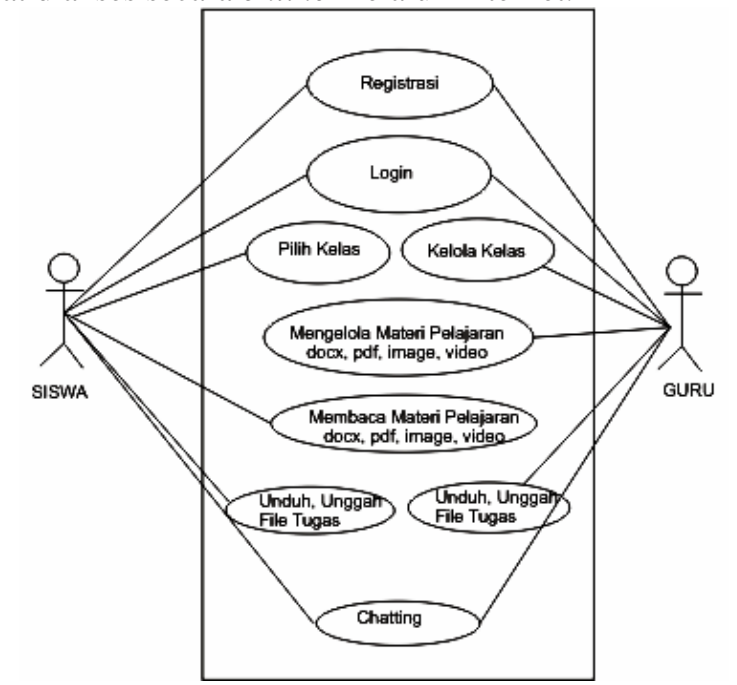

Gambar 3.Use case diagram model pembelajaranblended learning
Dari gambar use case diagram diatas dapat dijelaskan, bahwa setiap siswa harus registrasi kesistem agar terdaftar kedalam basis data. Apabila siswa sudah terdaftar di dalam sistem, makasiswa dapat login kesistem pembelajaran blended learning dan dapat mengunduh file-file pembelajaran dan lain-lain. Siswa juga dapat melakukan chatting dengan guru dan siswa lain yang terdaftar dalam sistem. Guru juga dapat memberikan tugas maupun quiz secara online kepada siswa.[13]

Secara umum penilaian aktivitas chat yang terjadi pada pembelajaran berbasis online lebih baik daripada pembelajaran tatap muka .Disinyalir terdapat beberapa faktor. Pertama, secara umum Peserta Didik pembelajaran berbasis online tampak lebih antusias daripada pembelajaran tatap muka saat pembelajaran di kelas. Hal ini tercermin dari jawaban-jawaban yang dilontarkan atas pertanyaaan yang diberikan oleh peneliti. Kedua, saat kegiatan diskusi pada pembelajaran berbasis online lebih berjalan lancar daripada pembelajaran tatap muka . Hal ini terlihat dari jawabanjawaban yang diberikan dan keseriusan dalam diskusi.

Penggunaan Aplikasi yang selam ini di manfaatkan, diantaranya :

\section{Aplikasi di classroom}

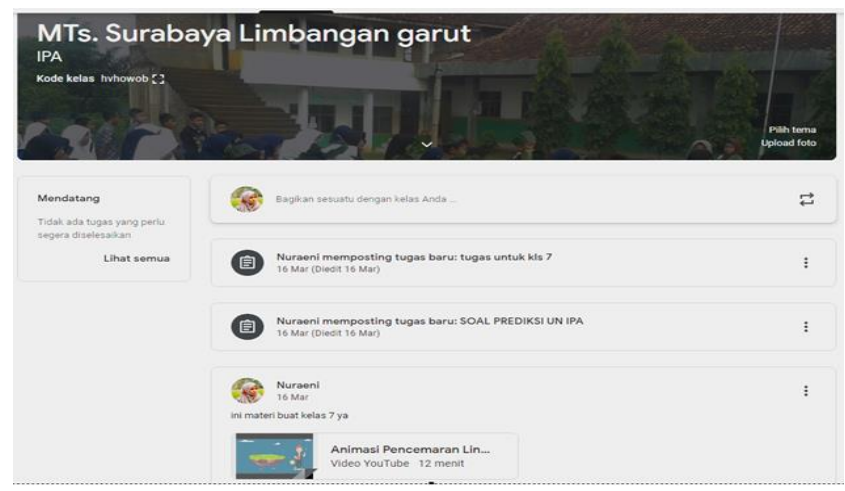

Gambar 4. Tampilan Aplikasi Classroom

2. Aplikasi di WAG

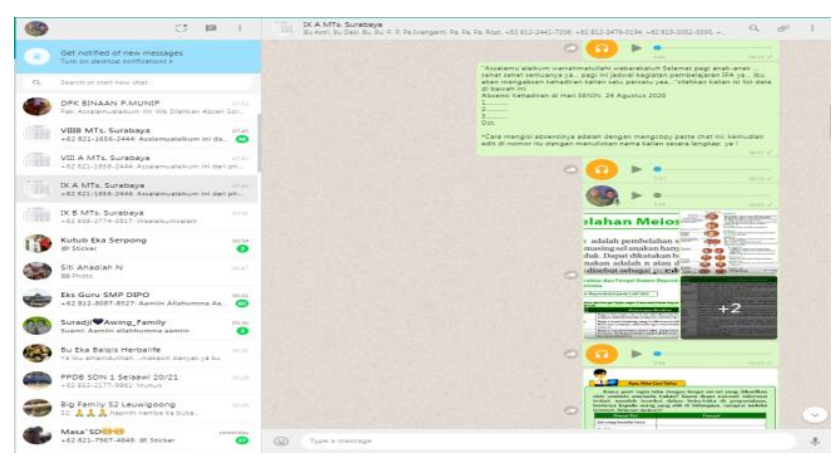

Gambar 5. Tampilan Aplikasi WhatsApp Web

1. Tampilan Pembuatan Soal dalam system aplikasi ISPRING 


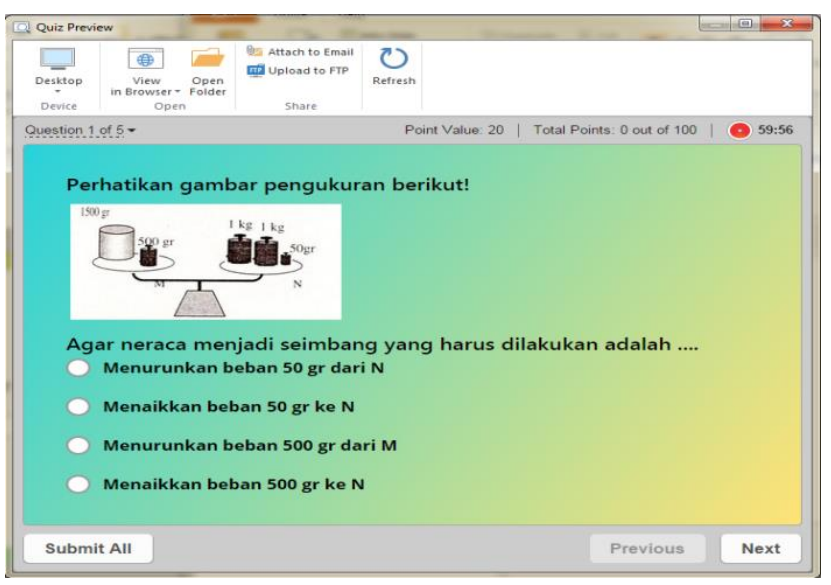

Gambar 6. Tampilan Aplikasi ISPRING

2. Modul untuk PJJ

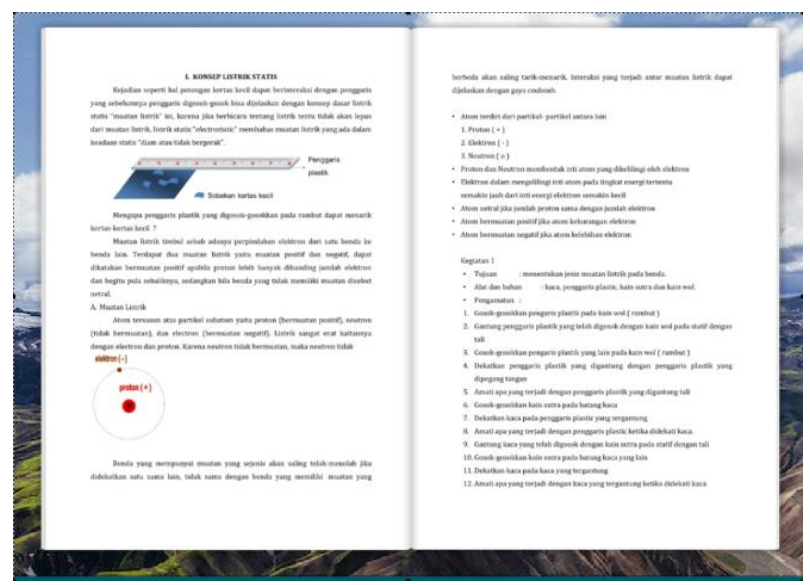

Gambar 7. Tampilan Modul PJJ

Pada pembelajaran blended learning sangat memungkinkan terjadinya interaksi pembelajaran dari mana dan kapan saja (time and place flexibility). Mengingat sumber belajar yang sudah dikemas secara elektronik dan tersedia untuk diakses oleh peserta didik melalui internet, maka murid dapat melakukan interaksi dengan sumber belajar ini kapan saja dan dari mana saja. Demikian juga dengan tugas-tugas kegiatan pembelajaran, dapat diserahkan kepada pengajar begitu selesai dikerjakan dan murid tidak terikat ketat dengan waktu dan tempat kegiatan pembelajaran sebagaimana halnya pada pendidikan konvensional.

Interaksi yang terjadi dalam pembelajaran blended dapat menunjang perubahan kognitif yang terjadi pada Peserta Didik. Hal ini ditunjukkan saat dilakukan diskusi online, antar Peserta Didik satu dengan yang lain akan saling bertukar pikiran untuk menyelesaikan pertanyaan. Kegiatan diskusi tersebut, secara tidak langsung memfasilitasi Peserta Didik untuk mengkonstruksi pengetahuannya sendiri. .Pertukaran pemikiran ini akan membentuk pemahaman tentang materi yang mereka bahas sehingga akan terjadi perubahan kognitif pada Peserta Didik.
Saat melakukan diskusi online, tampak beberapa Peserta Didik memberikan jawaban atas soal yang diberikan pengajar dengan memberikan link alamat web lain yang mereka cari sendiri sebagai alternative pengetahuan tambahan untuk menyelesaikan soal. Hal ini berarti mereka juga mencari sumber pengetahuan tambahan lain sumber belajar yang diberikan pengajar.

Berdasarkan hal tersebut, tampak bahwa konstruksi pemahaman Peserta Didik atau perubahan kognitif yang terjadi saat pembelajaran model blended learning terjadi saat Peserta Didik melakukan diskusi online. Sedangkan pada pertemuan di kelas, perubahan kognitif tidak terlalu terlihat karena Peserta Didik hanya mendengarkan materi yang diberikan oleh pengajar. Dengan kata lain, Peserta Didik hanya berlaku pasif dan lebih aktif jika mereka melakukan diskusi.

Secara umum penilaian aktivitas chat yang terjadi pada pembelajaran berbasis online lebih baik daripada pembelajaran tatap muka .Disinyalir terdapat beberapa faktor. Pertama, secara umum Peserta Didik pembelajaran berbasis online tampak lebih antusias daripada pembelajaran tatap muka saat pembelajaran di kelas. Hal ini tercermin dari jawaban-jawaban yang dilontarkan atas pertanyaaan yang diberikan oleh peneliti. Kedua, saat kegiatan diskusi pada pembelajaran berbasis online lebih berjalan lancar daripada pembelajaran tatap muka . Hal ini terlihat dari jawabanjawaban yang diberikan dan keseriusan dalam diskusi.

Hasil pengkajian yang diperoleh secara deskriptif menunjukkan bahwa sebagian besar Peserta Didik memberikan tanggapan puas terhadap penggunaan pembelajaran blended learning. Data kualitatif angket yang diperoleh dalam pengkajian ini berupa aspirasi atau masukan dari Peserta Didik tentang proses pembelajaran menggunakan blended learning.

Secara umum respon baik pada pembelajaran berbasis online lebih banyak daripada pembelajaran tatap muka . Hal ini menunjukkan bahwa pembelajaran berbasis online lebih tertarik dengan blended learning. Selain itu rata-rata Peserta Didik juga menyatakan mudah memahami materi dan senang dengan pembelajaran blended learning.

Berdasarkan hasil observasi dapat disimpulkan bahwa seluruh Peserta Didik menyenangi penggunaan blended learning dalam pembelajaran. Pernyataan ini didukung oleh aktivitas Peserta Didik selama kegiatan pembelajaran. Kepuasan Peserta Didik ini didukung oleh pelaksanaan pembelajaran yang menurut mereka lebih menarik karena melibatkan penggunaan media online.

Hasil belajar yang diperoleh peserta didik merupakan indikasi efektifitas penggunaan pembelajaran blended learning. Instrumen pengukuran hasil belajar melalui kuis dan tes yang diberikan pada peserta didik. Dengan pembelajaran blended learning diharapkan dapat menghasilkan hasil belajar yang baik. Beberapa analisis terhadap perbedaan hasil belajar pada pembelajaran dengan tatap muka dan Pembelajaran berbasis online yaitu: 
1. Motivasi belajar secara mandiri sangat diperlukan pada pembelajaran Blended, dengan demikian apabila dikaitkan dengan hasil belajar tampak bahwa motivasi belajar peserta didik berbasis online lebih besar daripada tatap muka.

2. Ditinjau dari pengalaman belajar menggunakan perpaduan kegiatan online, sebenarnya peserta didik pernah menggunakannya meskipun secara keseluruhan tidak sama dengan kegiatan belajar pada pengkajian ini. Sedangkan pembelajaran Blended Berbasis online, merupakan hal baru sehingga dimungkinkan memotivasi lebih tinggi.

3. Jika dibandingkan dengan peserta didik Berbasis online (60\% online) yang lebih banyak kesempatan untuk mengkonstruksi pengetahuannya sendiri, maka peserta didik dgn tatap muka ( $40 \%$ online) dimungkinkan masih bergantung pada kegiatan belajar dikelas sehingga referensi pengetahuan yang dimiliki terbatas pada penyampaian materi di kelas.

4. Ditinjau dari atmosfer belajar saat dikelas, pada saat peneliti menyampaikan materi baik itu materi ajar ataupun penjelasan penggunaan web yang akan dilakukan menunjukkan respon Berbasis online lebih antusias daripada Tatap muka.

Aplikasi classroom dan WAG menurut saya sangat efektif karena walaupun kita tidak bisa berinteraksi langsung secara visual, kita hanya bisa diskusi dalam bentuk chat. kemudian pemberian materipun hanya di berikan dalam bentuk file saja tanpa adanya penjelasan yang rinci sehngga menyulitkan kita untuk memahami materi dengan cepat, dengan WAG semua kalangan siswa dan orang tua sebahagian besar

Jika dilihat dari analisis perencanaan dan persiapan untuk MTs. Surabaya aplikasi yang lebih efektif dan efisien adalah WAG dan goggle classroom, dengan aplikasi ini bisa memenuhi kebutuhan proses pembelaajran dengan cukup seperi guru sudah menyediakan mater yang akan di sampaikan dalam bentuk E-modul, Power Point yang di padukan dengan ispring, kuis-kuis interaktif dengan penggunaan aplikasi interaktif atau dalam bentuk word kemudian di sahre di grup yang sudah tersedia, peserta didik pun akan lebih mudah mengaksesnya. interaksinya pun bias dilihat seberapa besar keaktifan dan respon peserta didik yang terlibat mengikuti pembelajaran. Bias juga dengan cukup menanggapi materi yang di sampaikan dalam bentuk chating.

Sedangkan aplikasi zoom meeting, webex, big bleu botton, e-learning memerlukan persiapan yang cukup matang dengan menghadirkan seorang moderator atau ahli IT untuk membuat alamat berupa link ID meeting dan password untuk bisa masuk atau mengakses aplikasi tersebut. Karena dalam pembuatan pembelajaran interaktif dalam pengembangan multimedia dengan internet dilakukan dengan software yang berbasis html, setelah program selesai di buat dapat lansung di publish menjadi file html. (Darmawan.2014:82)

Dalam pembelajaran klasikal, proses belajar peserta didik terikat oleh dimensi ruang dan waktu, artinya peserta didik harus berada dalam ruang dan waktu yang sama dengan teman sekelas dan guru untuk melakukan kegiatan pembelajaran. Jika peserta didik tidak mampu datang pada salah satu kegiatan pembelajaran, ini berarti bahwa peserta didik tersebut akan kehilangan kesempatan untuk mendapatkan pengetahuan dan skill yang baru. Oleh karena itu, perlu dicari alternatif untuk pembelajaran klasikal yang bisa mengatasi masalah tersebut tanpa menghilangkan perasaan ikatan sosial antara peserta didik dengan teman sekelasnya maupun antara peserta didik dengan gurunya. Dengan kata lain, pembelajaran tidak hanya cukup dengan melakukan tatap muka klasikal seperti yang selama ini dilakukan.[14]

Proses pembelajaran di masa new normal ini, akan lebih efektif dengan mengunakan pendekatan dan mekanisme blended learning. Pendekatan blended learning, yakni menggabungkan pendekatan daring dan luring (luar jaringan). pendekatan blended learning, tentu dengan segala kelebihan dan kekurangannya, cenderung dapat dijadikan alternatif strategis. Pendekatan blended learning pada dasarnya merupakan gabungan keunggulan pembelajaran yang dilakukan secara tatap-muka (luring) dan secara virtual (daring). Ia akan menggabungkan berbagai cara penyampaian, model pengajaran, dan gaya pembelajaran, dengan berbagai pilihan media dialog antara pendidik dengan peserta didik, baik secara langsung (face-to-face) maupun secara daring. Menggabungkan kelebihan-kelebihan pada kedua cara tersebut dalam sebuah proses pembelajaran yang efektif merupakan ciri dari blended learning. [15]

Proses pembelajaran dengan penerapan pembelajaran campuran (blended learning) khusus diperlukan untuk mempermudah siswa dalam memahami Mata Pelajaran IPA, sehingga dapat meningkatkan hasil belajar siswa. Salah satu dengan memanfaatkan teknologi informasi adalah blended learning. (Izzudin, 2012: 14). Blended learning adalah kombinasi karakteristik pembelajaran tradisional dan lingkungan pembelajaran elektronik. Blended learning menggabungkan aspek pembelajaran berbasis web (internet) dengan pembelajaran tradisional "tatap muka" (Sjukur, 2012: 4). Penerapan blended learning diharapkan siswa dapat memahami materi dengan lebih baik dan lebih aktif dalam mengikuti pembelajaran, sehingga dapat meningkatkan hasil belajar siswa.

\section{KESIMPULAN}

Berdasarkan hasil pengkajian dan pembahasan yang telah diuraikan, maka dapat dikemukakan beberapa kesimpulan sebagai berikut:

1. Dalam pembelajaran dengan blended learning peserta didik saling berinteraksi secara aktif. Hal ini ditunjukkan dengan tingginya frekuensi dan kualitas interaksi peserta didik dengan pertemuan $60 \%$ online.

2. menunjukkan interaksi belajar antar peserta didik lebih sering daripada dengan $40 \%$ online.

3. Sebagian besar peserta didik merasa puas terhadap pembelajaran dengan model blended learning. 
Pembelajaran blended learning dengan $60 \%$ online menunjukkan hasil belajar yang lebih efektif dibandingkan dengan $40 \%$ online.

4. Dilihat dari interaksi peserta didik dan respon pengerjaan tugas dengan pembelajaran blended learnin kemampuan peserta didik dapat mencapai kriteria kelulusan minimal.

\section{UCAPAN TERIMA KASIH}

Terima kasih kepada seluruh pihak yang berperan memberikan kelancaran dan kemudahan dalam pengambilan informasi penelitian yang kami lakukan terutama staff dan kepala sekolah di Mts. Surabaya Limbangan Kabupaten Garut.

\section{DAFTAR PUSTAKA}

[1] D. Jamaluddin, T. Ratnasih, H. Gunawan, and E. Paujiah, "Pembelajaran Daring Masa Pandemik Covid-19 Pada Calon Guru : Hambatan, Solusi dan Proyeksi," Karya Tulis Ilm. UIN Sunan Gunung Djjati Bandung, pp. 1-10, 2020, [Online]. Available: http://digilib.uinsgd.ac.id/30518/.

[2] D. Darmawan and U. P. Indonesia, "Learning Communication Strategy on EducationalSustainability Developmentin Primary Education Level at Bandung Municipality," vol. 10, no. January 2015, pp. 1999-2005, 2018.

[3] D. Darmawan, H. Kartawinata, and W. Astorina, "Development of web-based Electronic Learning System (WELS) in improving the effectiveness of the study at vocational high school 'Dharma Nusantara,"” J. Comput. Sci., vol. 14, no. 4, pp. 562-573, 2018, doi: 10.3844/jessp.2018.562.573.

[4] B. Philipsen and V. U. Brussel, "Online And Blended Learning In Adult Dissertation submitted to the Faculty of Psychology and Educational Sciences in partial," no. January, 2019, doi: 10.13140/RG.2.2.13695.87205.

[5] P. Schwarz et al., "No Title شيمى مو اد غذايى," Eur. J. Endocrinol., vol. 171, no. 6, pp. 727-735, 2014, doi: 10.1530/EJE-14-0355.

[6] I. A. Nell, "Blended learning: Innovation in the teaching of practical theology to undergraduate students," HTS Teol. Stud. / Theol. Stud., vol. 69, no. 1, pp. 1-8, 2013, doi: 10.4102/hts.v69i1.1241.

[7] N. Noviansyah, "Pembelajaran Bauran Blended Learning) Terampil Memadukan Keunggulan Pembelajaran Face-to-Face, E-Learning Offline-Online dan Mobil Learning," At-Turats, vol. 9, no. 2, p. 75, 2015, doi: 10.24260/at-turats.v9i2.318.

[8] H. Hidayatullah, "Peran Pusat Sumber Belajar Dalam Meningkatkan Mutu Pendidikan," Alqalam, vol. 22, no. 2, p. 191, 2005, doi: 10.32678/alqalam.v22i2.1377.

[9] S. Dan and D. Sma, "Pengembangan E-Modul Berbasis Web Untuk Meningkatkan Pencapaian Kompetensi Pengetahuan Fisika Pada Materi Listrik," vol. 3, no. 2, pp. 51-61, 2018.

[10] E. W. Wulansari, S. Kantun, and P. Suharso, "Pengembangan EModul Pembelajaran Ekonomi Materi Pasar Modal Untuk Siswa Kelas Xi Ips Man 1 Jember Tahun Ajaran,” vol. 12, pp. 1-7, 2018, doi: 10.19184/jpe.v12i1.6463.

[11] N. Mahnun, "Media Pembelajaran (Kajian terhadap Langkah-langkah Pemilihan Media dan Implementasinya dalam Pembelajaran)," anNida', vol. 37, no. 1, pp. 27-35, 2012.

[12] Badriyah, "Efektifitas Proses Pembelajaran Dengan Pemanfaatan," $J$. Lentera Komun., vol. 1, no. 1, pp. 21-36, 2015.

[13] A. Rizkiyah, "Penerapan Blended Learning untuk Meningkatkan Hasil Belajar Siswa pada Mata Pelajaran Ilmu Bangunan di Kelas X TGB SMK Negeri 7 Surabaya," J. Kaji. Pendidik. Tek. Bangunan, vol. 1, no. 1, pp. 40-49, 2013.

[14] H. Andi, "Peran Pengembangan Dan Pemanfaaatan Teknologi Pendidikan Dan Pembelajaran Dalam Meninggkatkan Kualitas Mengajar," J. Chem. Inf. Model., vol. 53, no. 9, pp. 1689-1699, 2011, doi: 10.1017/CBO9781107415324.004.

[15] Suhartono, "Menggagas Penerapan Pendekatan Blended Learning Di Sekolah Dasar Suhartono Blended Learning Approach Initiating Application Instructional media such as books, globes, and other students are learning in Menggagas Penerapan Pendekatan Blended Learning Di," J. Kreat., pp. 177-188, 2017. 